Yanishen I. V., Sidorova O. V., Berezhna O. O., Saliya L. G., Bugaiev V. Y. Analysis of the terms of usage of non-removable restorations fixed by different glass ionomer cements. Journal of Education, Health and Sport. 2021;11(12):307-319. eISSN 2391-8306. DOI http://dx.doi.org/10.12775/JEHS.2021.11.12.024

https://apcz.umk.pl/JEHS/article/view/JEHS.2021.11.12.024

https://zenodo.org/record/5802102

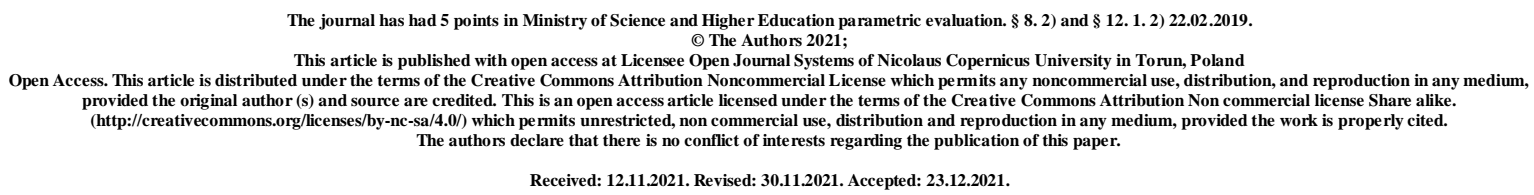

UDK 616.314-77-085.463-073-035

\title{
Analysis of the terms of usage of non-removable restorations fixed by different glass ionomer cements
}

\author{
I. V. Yanishen, O. V. Sidorova, O. O. Berezhna, L. G. Saliya, V. Y. Bugaiev
}

\section{Kharkiv National Medical University}

Igor Yanishen - ORCID:0000-0003-4278-5355

Olha Sidorova - ORCID:0000-0002-4979-1291, helgasid13@ukr.net

Olena Berezhna - ORCID:0000-0003-4221-4608

Liya Saliya - ORCID:0000-0002-3807-5468

Vladyslav Bugaiev - ORCID:0000-0003-1432-8229)

\section{Abstract}

Preservation and restoration of dental health of patients is achieved by early detection and treatment of diseases, finding ways of individual prevention, detection and elimination of risk factors for their development. The amount of materials significantly increased used to restore the integrity of teeth and dentition. Among them are dental materials for permanent fixation of indirect non-removable restorations. The material is used to fill the space between the inner surface of the artificial structure and the support element. This helps to mechanically fix the restoration in place to prevent its displacement during chewing. The correct choice of dental material for permanent fixation is an important decision and will determine the long-term success 
of permanent restorations. The aim of the study is to analyze the durability using non-removable structures of dentures mounted on different glass ionomer cements.

Keywords: glass ionomer cement; fixation; non-removable dentures; hard tissues of the supporting teeth.

Introduction. Restoring and improving the quality of life and dental health of the population is approximately $80-90 \%$ of the adult population $[1,2]$. From the studies of various authors, it is known that the restoration of the integrity of the dentition contributes not only to the normalization of the maxillofacial apparatus, anatomical and morphological relationships and aesthetic norms, but also prevention of gastrointestinal diseases and psychoemotional state of the patient $[3,4]$. The quality of orthopedic treatment of dental defects and limited dentition defects depends on many factors $[5,6]$.

The constant increase in the quantity of materials used to restore the integrity of teeth and dentition has increased significantly in recent decades [7]. Dental materials for permanent fixation of indirect restorations are also being developed. The main function of this material is to fill the gaps between the inner surface of the artificial structure and the supporting element and mechanically fix the restoration in place to prevent its displacement during chewing $[8,9,10]$. The correct choice of dental material for permanent fixation is an important decision and will determine the long-term success of fixed restorations [11].

In recent years, many fixing materials and dental cements have been introduced that have clinically better characteristics than existing materials due to improved characteristics. Previously, the choice was easy due to the presence of only one material for fixation - zincphosphate cement [12].

Now choosing the optimal fixing cement can be quite difficult even for the most experienced clinician. Restorations of metal, metal-fused porcelain, low- and high-strength ceramics require a balanced approach, and the right choice of cement should be based on knowledge of physical properties, biological properties and other properties as restoration materials [13].

The aim of the study. Analyze the durability of the usage of fixed structures of dentures fixed on different glass ionomer cements. 
Materials and methods. Our study was conducted on the Department of Orthopedic Dentistry on the University Dental Center of Kharkiv National Medical University. Fifty patients were examined and treated. Fixed prostheses (50 non-removable dentures) were made for them using traditional methods, including: single crowns (stamped, cast, metal-ceramic), pin designs (metal) and dental bridges (stamped-soldered, cast, combined). Patients were divided into three clinical groups depending on the dental material used for permanent fixation. The first group included patients with non-removable dentures fixed by the group of glass ionomer cements based on a mixture of carboxylic and maleic acids (3M ESPE, Germany - GIC based on CMA), in the second group used material obtained by mixing on a homopolymer of acrylic and tartaric acid (SDI Limited, Australia - GIC based on ATA), in group III used new proposed glass ionomer cement obtained by mixing polycarboxylic and 2,3-dihydroxybutadione acids (JSC "Stoma", Ukraine - GIC based on PCTA)

Results and discussion. The obtained results of comparison of indicators of PMA index (in Parma modification) in group I in 7 days after fixing 41.34 (3.41) \% in comparison with PMA index in 6 months 54.29 (4.18) \% indicate reliability of results $(\mathrm{p}<0.05)$ (Table 1).

Comparison of the PMA index in patients of group II 7 days after fixation 48.27 (3.72) \% indicates the inaccuracy of values ( $>>0.05)$, compared with the PMA index for six months in patients of group II was 51.91 (6.23) \%, indicating the inaccuracy of the results ( $>0.05)$, compared with data after 12 months 48.76 (4.08) \%.

Determination of the marginal periodontal inflammation index in patients of group III for 7 days of use of fixed dentures 32.75 (2.39) \% with data after 6 months in patients of group III PMA index was 42.14 (3.15) \%, which indicates on the reliability $(\mathrm{p}<0.05)$ of the data. After 12 months of using non-removable dentures in patients of group III, the index of inflammation of the marginal periodontium was 39.19 (3.17) \%, which has no significant difference (p>0.05) (Fig. 1).

The mismatch of the marginal fit of non-removable dentures 7 days after fixation in patients of group I revealed about 1 structure 6.67 (1.47) \% of the total in the group, indicating the reliability of the values $(\mathrm{p}<0,01)$ when comparing the data review of this group after 6 months, the figure 46.67 (5.37) \% was 7 non-removable dentures. In group II, this phenomenon was detected in 4 fixed dentures, 26.67 (1.82) \%, which is slightly different from the figure for 7 days, which rocked 3 fixed dentures $20.00(2.42) \%$ and has an inaccurate value (p>0.05). 
Table 1

Indicators of criteria for assessing the quality of fixation of non-removable dentures

for a certain period of usage

\begin{tabular}{|c|c|c|c|c|c|c|c|c|c|c|}
\hline \multirow[b]{2}{*}{$\begin{array}{l}\text { Review } \\
\text { deadline }\end{array}$} & \multirow{2}{*}{$\begin{array}{l}\text { Clinical } \\
\text { group of } \\
\text { patients }\end{array}$} & \multicolumn{9}{|c|}{ Criteria evaluation } \\
\hline & & \multirow{2}{*}{\begin{tabular}{|l}
$\begin{array}{l}\text { PMA } \\
\text { index }\end{array}$ \\
41.34 \\
$(3.41)^{\mathrm{a} 1}$
\end{tabular}} & \multicolumn{2}{|c|}{$\begin{array}{c}\text { Violation } \\
\text { of the marginal } \\
\text { fit }\end{array}$} & \multicolumn{2}{|c|}{\begin{tabular}{|c|}
$\begin{array}{c}\text { Violation of the } \\
\text { stability of the } \\
\text { dentures }\end{array}$ \\
\end{tabular}} & \multicolumn{2}{|c|}{$\begin{array}{c}\text { Changes of } \\
\text { color }\end{array}$} & \multicolumn{2}{|c|}{$\begin{array}{c}\text { Permanent } \\
\text { fixation without } \\
\text { violations }\end{array}$} \\
\hline \multirow{3}{*}{$\begin{array}{l}7 \text { days after } \\
\text { fixing the } \\
\text { denture }\end{array}$} & & & 1 & $\begin{array}{l}6.67 \\
(1.47)^{\mathrm{d} 1}\end{array}$ & 2 & $\begin{array}{l}13.33 \\
(1.32)^{\mathrm{d} 1}\end{array}$ & - & - & 12 & \begin{tabular}{|l|}
80.00 \\
$(4.18)^{\mathrm{d} 1}$
\end{tabular} \\
\hline & $\begin{array}{l}\text { III } \\
(\mathrm{n}-15)\end{array}$ & $\begin{array}{l}48.27 \\
(3.72)\end{array}$ & 3 & $\begin{array}{l}20.00 \\
(2.42)\end{array}$ & 2 & $\begin{array}{l}13.33 \\
(2.12)^{\mathrm{e} 1}\end{array}$ & - & | & 10 & $\begin{array}{l}66.67 \\
(5.31)^{\mathrm{e} 1}\end{array}$ \\
\hline & $\begin{array}{l}\text { III } \\
(\mathrm{n}-20)\end{array}$ & $\begin{array}{l}32.31 \\
(2.39)^{\mathrm{cl}}\end{array}$ & 1 & $\begin{array}{l}5.00 \\
(0.62)\end{array}$ & - & & 1 & $\begin{array}{l}5.00 \\
(1.42)^{\mathrm{c} 1}\end{array}$ & 18 & $\begin{array}{l}90.00 \\
(5.21)^{f 1}\end{array}$ \\
\hline Total & 50 & & 5 & & 4 & & 1 & & 40 & \\
\hline \multirow{3}{*}{$\begin{array}{l}6 \text { months after } \\
\text { fixing the } \\
\text { denture }\end{array}$} & $\begin{array}{l}\text { I } \\
(n-15)\end{array}$ & $\begin{array}{l}54.29 \\
(4.08)\end{array}$ & 7 & $\begin{array}{l}46.67 \\
(5.37)\end{array}$ & 4 & $\begin{array}{l}26.67 \\
(3.41)\end{array}$ & 2 & $\begin{array}{l}13.33 \\
(2.68)^{d}\end{array}$ & 2 & $\begin{array}{l}13.33 \\
(1.84)\end{array}$ \\
\hline & $\begin{array}{l}\text { II } \\
(n-15)\end{array}$ & $\begin{array}{l}51.91 \\
(6.23) \\
\end{array}$ & 4 & $\begin{array}{l}26.67 \\
(4.82)\end{array}$ & 5 & $\begin{array}{l}33.33 \\
(4.27)^{\mathrm{e} 2}\end{array}$ & 4 & $\begin{array}{l}26.67 \\
(2.13)\end{array}$ & 2 & $\begin{array}{l}13.33 \\
(1.53)^{\mathrm{e} 2}\end{array}$ \\
\hline & $\begin{array}{l}\text { III } \\
(n-20)\end{array}$ & $\begin{array}{l}42.14 \\
(3.15)\end{array}$ & 4 & $\begin{array}{l}20.00 \\
(2.54)\end{array}$ & 2 & $\begin{array}{l}10.00 \\
(2.24)\end{array}$ & 2 & $\begin{array}{l}10.00 \\
(1.47)\end{array}$ & 12 & $\begin{array}{l}60.00 \\
(5.38)\end{array}$ \\
\hline Total & 50 & & 15 & & 11 & & 8 & & 16 & \\
\hline \multirow{3}{*}{$\begin{array}{l}12 \text { months } \\
\text { after fixing the } \\
\text { dentures }\end{array}$} & $\begin{array}{l}\mathrm{I} \\
(\mathrm{n}-15)\end{array}$ & $\begin{array}{l}43.52 \\
(3.02) \\
\end{array}$ & 5 & $\begin{array}{l}33.33 \\
(3.68) \\
\end{array}$ & 3 & $\begin{array}{l}20.00 \\
(1.53) \\
\end{array}$ & 2 & $\begin{array}{l}13.33 \\
(3.41) \\
\end{array}$ & 5 & $\begin{array}{l}33.33 \\
(4.67)^{\mathrm{d} 1}\end{array}$ \\
\hline & $\begin{array}{l}\text { II } \\
(\mathrm{n}-15)\end{array}$ & $\begin{array}{l}48.76 \\
(4.08)\end{array}$ & 6 & $\begin{array}{l}40.00 \\
(3.87)\end{array}$ & 2 & $\begin{array}{l}13.33 \\
(2.37)\end{array}$ & 3 & $\begin{array}{l}20.00 \\
(4.28)\end{array}$ & 4 & $\begin{array}{l}26.67 \\
(3.62)\end{array}$ \\
\hline & $\begin{array}{l}\text { III } \\
(n-20)\end{array}$ & $\begin{array}{l}39.19 \\
(3.17) \\
\end{array}$ & 3 & $\begin{array}{l}15.00 \\
(3.16)\end{array}$ & 3 & $\begin{array}{l}15.00 \\
(2.07)\end{array}$ & 2 & $\begin{array}{l}10.00 \\
(1.56)\end{array}$ & 12 & $\begin{array}{l}60.00 \\
(3.87) \\
\end{array}$ \\
\hline Total & 50 & & 14 & & 8 & & 7 & & 21 & \\
\hline \multicolumn{11}{|c|}{$\begin{array}{l}\text { a1 - significant differences in group I between } 7 \text { days and } 6 \text { months at the level of } p<=0.05 \\
\text { a2 - significant differences in group I between } 6 \text { and } 12 \text { months at the level of } p<=0.05 \\
\text { b1 - significant differences in group II between } 7 \text { days and } 6 \text { months at the level of } p<=0.05 \\
\text { b2 - significant differences in group II between } 6 \text { and } 12 \text { months at the level of } p<=0.05 \\
\text { c1 - significant differences in group III between } 7 \text { days and } 6 \text { months at the level of } p<=0.05 \\
\text { c2 - significant differences in group III between } 6 \text { and } 12 \text { months at the level of } p<=0.05 \\
\text { d1 - significant differences in group I between } 7 \text { days and } 6 \text { months at the level of } p<=0,01 \\
\text { d2 - significant differences in group I between } 6 \text { and } 12 \text { months at the level of } p<=0.01 \\
\text { e1 - significant differences in group II between } 7 \text { days and } 6 \text { months at the level of } p<=0.01 \\
\text { e2 - significant differences in group II between } 6 \text { and } 12 \text { months at the level of } p<=0.01 \\
\text { f1 - significant differences in group III between } 7 \text { days and } 6 \text { months at the level of } p<=0.01 \\
\text { f2- significant differences in group III between } 6 \text { and } 12 \text { months at the level of } p<=0.01\end{array}$} \\
\hline
\end{tabular}




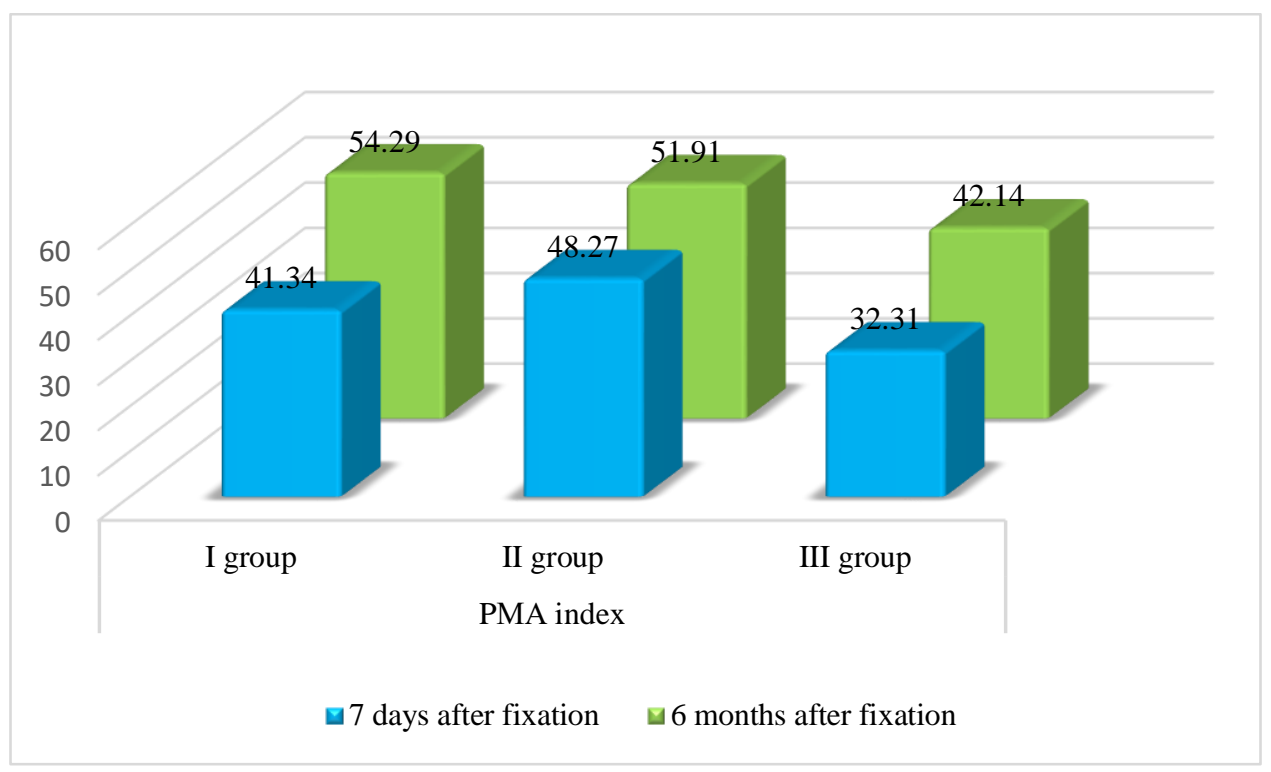

Fig. 1. PMA index in comparison between indicators for 7 days and 6 months after fixation of non-removable dentures

In patients of group III violation of the marginal fit during the first 7 days after fixation was observed in 1 design of the denture 5.00 (0.62) \%, and after 6 months these data 20.00 (2.54) $\%$, which indicates the reliability $(\mathrm{p}<0.01)$ results (fig. 2$)$.

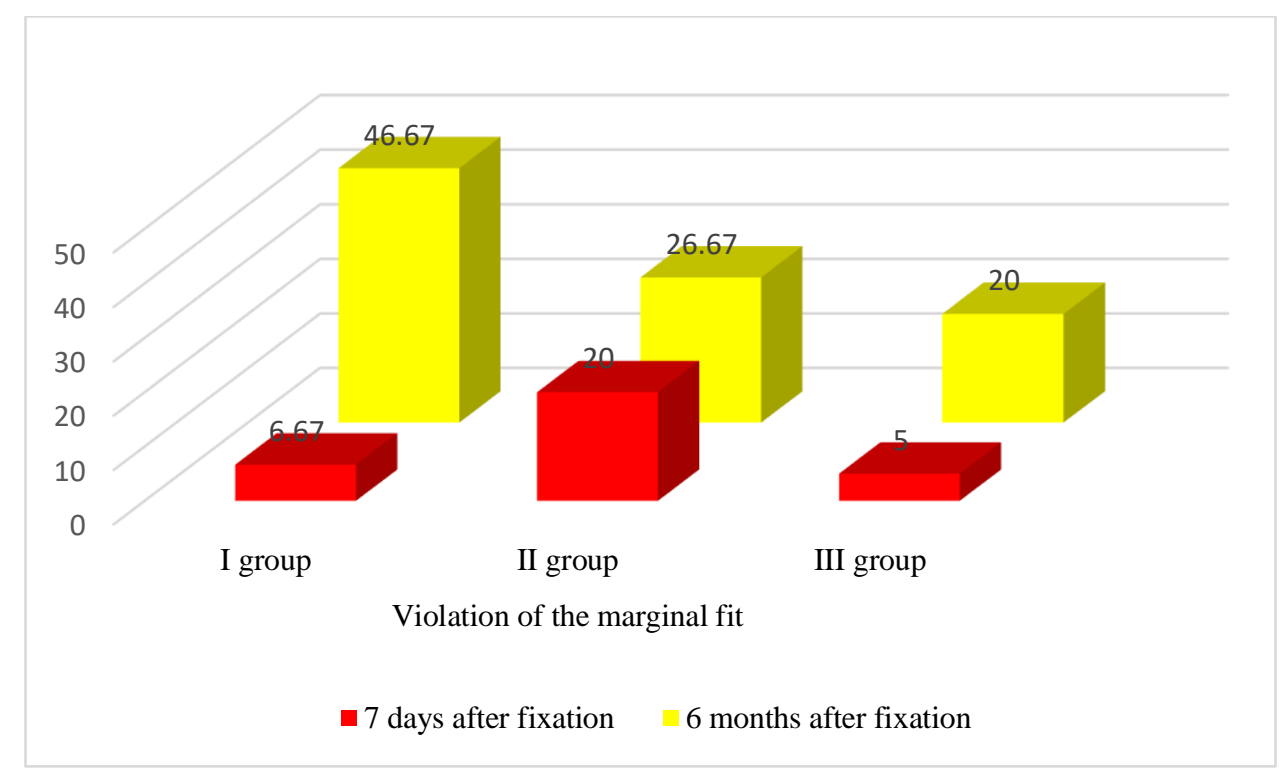

Fig. 2. Comparison of the indicators of the marginal fit of the fixed dentures between the data for 7 days and 6 months after fixation 
Violation of dentures`stability after 7 days was found in patient`s group I in about 2 fixed prostheses $13.33(1.32) \%$, and after 6 months - in 4 structures 26.67 (3.41) \%, which indicates the reliability $(\mathrm{p}<0.01)$. In the second group for the first 7 days was observed in 2 constructions 13.33 (2.12) \%, which from 6 monthly 33.33 (7.27) \%, which indicates 5 units, indicates the reliability of the aggregates $(\mathrm{p}<0.01)$. Patients of group III of the violation of stability were observed about 2 fixed prostheses 10.00 (2.24) \% in contrast to the data for 7 days when this indicator was not in this group at all.

The changes in the color of dentures was observed only in group III of patients 5.00 (1.42) \% during the first 7 days, and after 6 months 10.00 (1.47) \%, which indicates the reliability $(\mathrm{p}<0.05)$ data, in contrast to groups I and II. After 6 months of usage, this indicator was noted in group I - 2 prostheses 13.33 (2.68) \%, and in group II 4 prostheses 54.29 (4.08) \% (fig. 3).

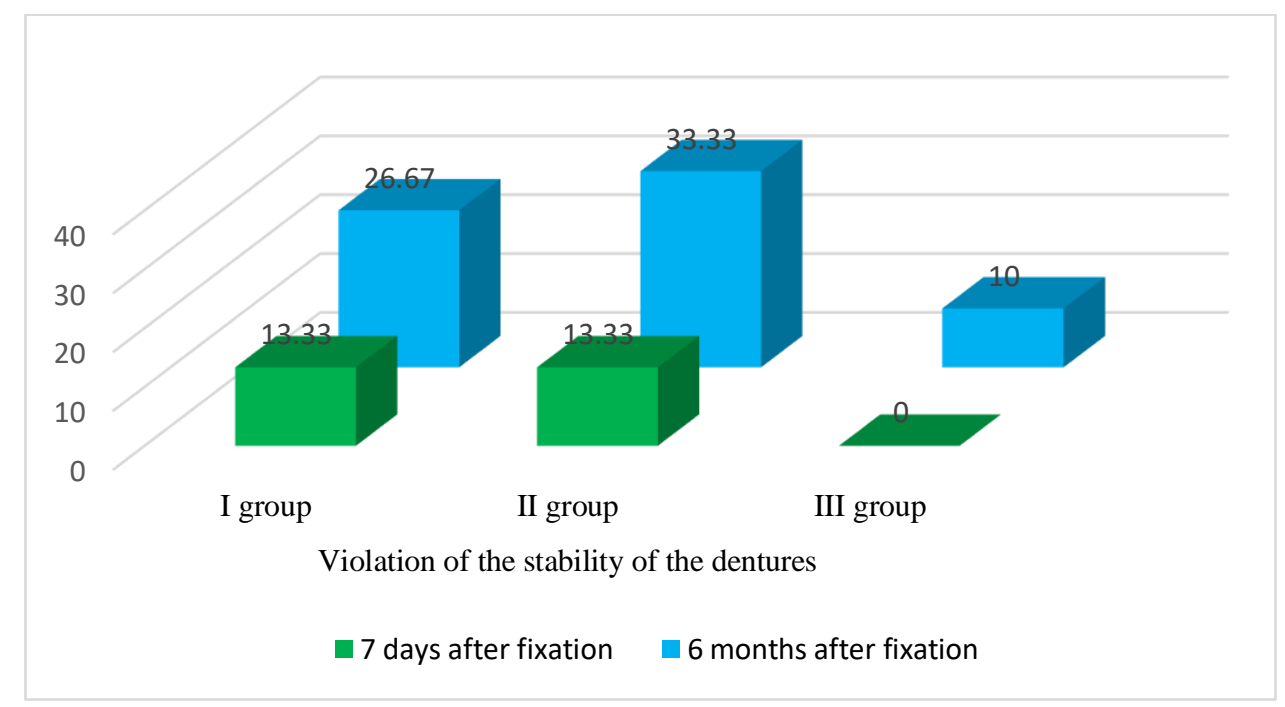

Fig. 3. Comparison of the stability of the fixed dentures over a period between 7 days and 6 months after permanent fixation

There were fixed dentures without violation of permanent fixation. During the first 7 days these fixed prostheses were observed in group I - 12 patients 80.00 (4.18) \%, after 6 months in this group of patients were observed - 2 units 13.33 (1.84) \%, which indicates reliable values $(\mathrm{p}<0.01)$ (fig. 4). 


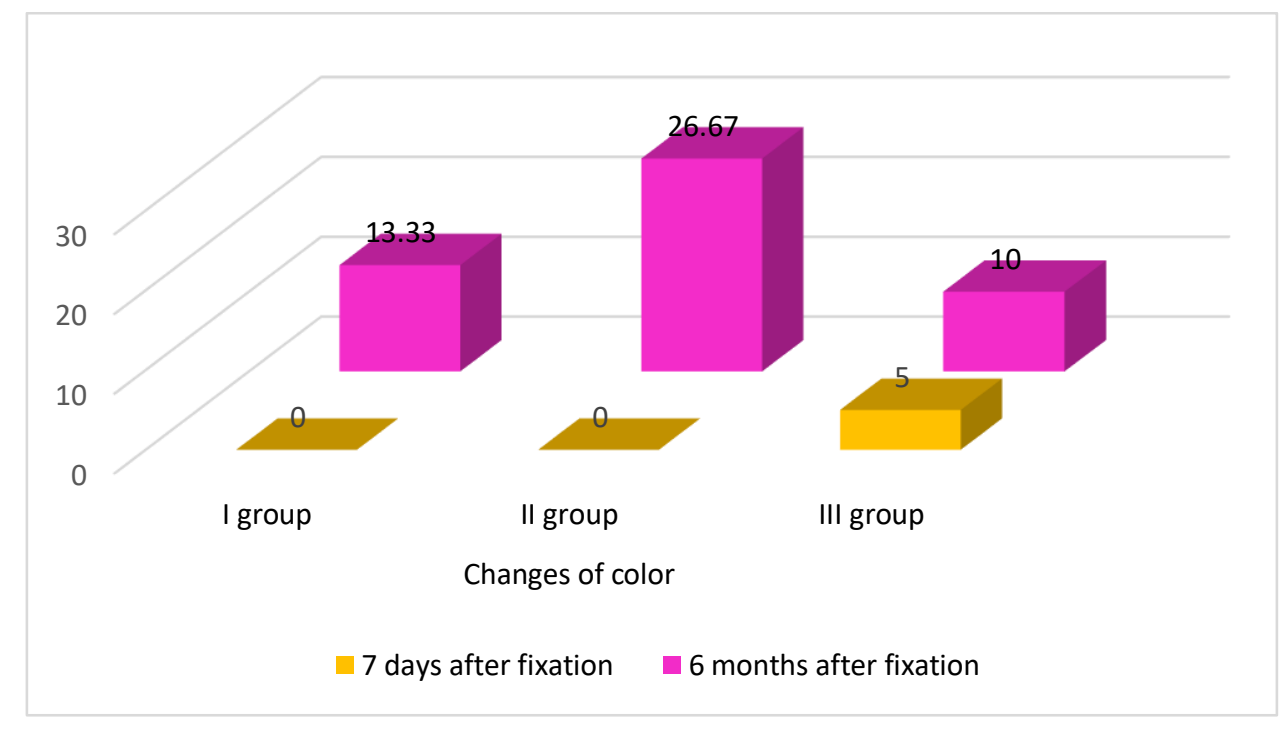

Fig. 4. Comparison of the changes in the color of fixed dentures over a period between 7 days and 6 months after permanent fixation

For 7 days after fixation in patients of the II group of structures without violation of fixation was 10 non-removable dentures 66.67 (5.31) \%, for 6 months it is 2 non-removable dentures $13.33(1.53) \%$, the results obtained indicate reliability $(\mathrm{p}<0.01)$. In patients of group III, 18 constructions 90.00 (5.21) \% were noted for the first 7 days, but after 6 months of use the indicator had 12 fixed dentures 60.00 (5.38) \% and indicated significant ( $<<0.01)$ results (fig. 5).

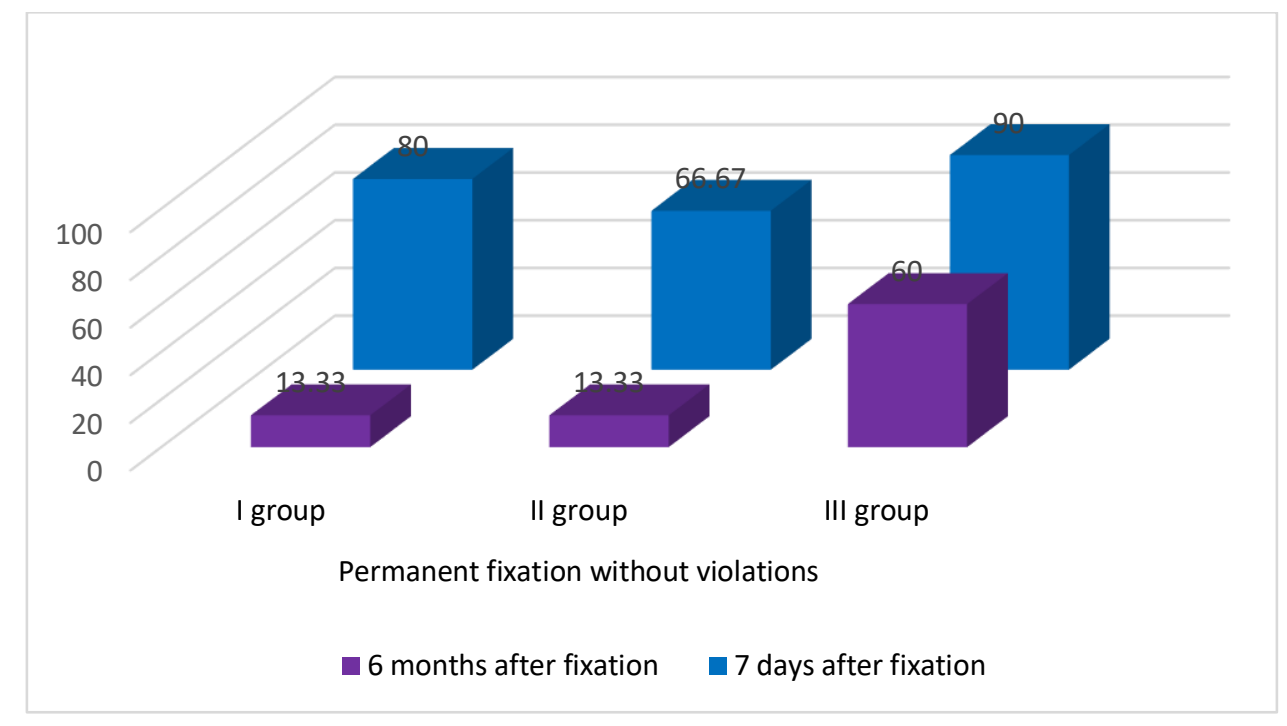

Fig. 5. Comparison of indicators of "dentures without violation of fixation" over a period between 7 days and 6 months after permanent fixation 
At the planned examination of patients after 12 months (Table 1) after the fixation of fixed dentures in the objective examination showed a decrease in the PMA index in group I of patients 43.52 (3.02) \% in contrast to the 6-month rate 54.29 (4.08) \%, indicating the reliability of the population $(\mathrm{p}<0.05)$, in group II inflammation of the marginal periodontium was small 48.76 (3.72)\%, and indicated inaccuracy of data $(\mathrm{p}>0.05)$, according to preliminary results 51.91 (6.23)\% (fig. 6).

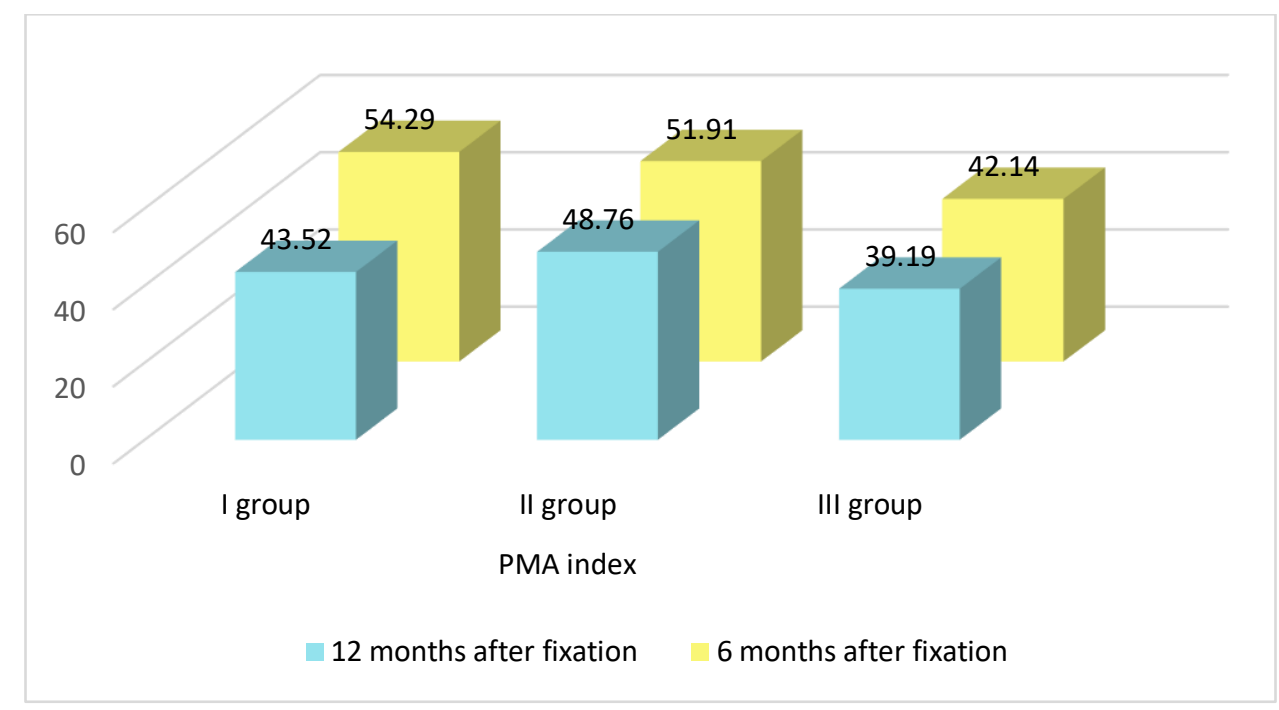

Fig. 6. PMA index of comparison over a period between 6 and 12 months after permanent fixation of non-removable dentures

In patients of group III, this indicator for 12 months had an indicator 39.19 (3.17) \% and indicated the insignificance ( $\mathrm{p}>0.05$ ) of the results obtained compared with 6-month data 42.14 (3.15) \%.

Criterion of marginal fit of fixed dentures after a year of usage was violated in group I of patients - about 5 constructions 33.6 (3.18) \%, but for a 6-month period it was found -7 units 46.6 (5.37) \%, which indicates the reliability of $(\mathrm{p}<0.05)$ the results (fig. 7). 


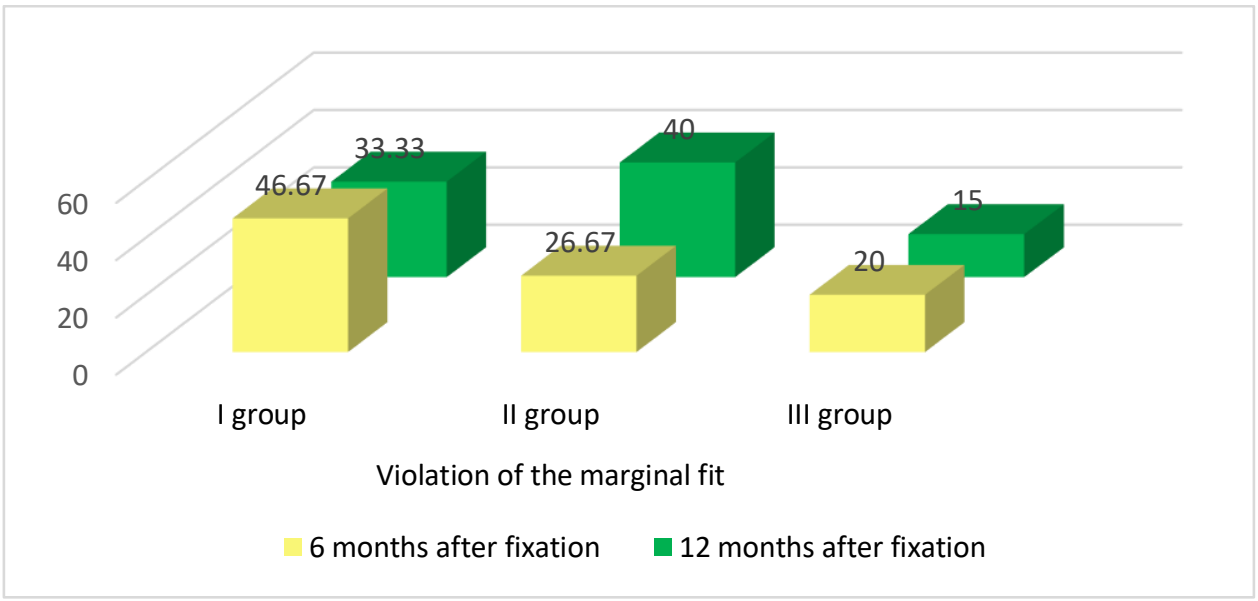

Fig. 7. Comparison of the indicators of violation of the marginal fit of the fixed dentures over a period between 6 and 12 months after fixation

The marginal fit in group II was broken in 4 units 26.67 (1.82) \% for a 6-month period and about 6 fixed dentures 40.00 (3.87) \% after 12 months of usage and indicates the reliability of the statistics $(\mathrm{p}<0.05)$ (fig. 7).

When examining patients of group III, this deficiency was found in 3 units 15.00 (3.16) $\%$, which differs slightly from the 12-month results of 4 fixed dentures 20.00 (2.42) \% and indicates the inaccuracy of statistical indicators $(\mathrm{p}>0.05)$. Violation of the stability of the fixed dentures in group I was observed in 12 months in 3 units 20.0 (1.53) \%, which indicates the inaccuracy of statistical results ( $p>0.05$ ) compared with 6 months 26.67 (3.41) \%.

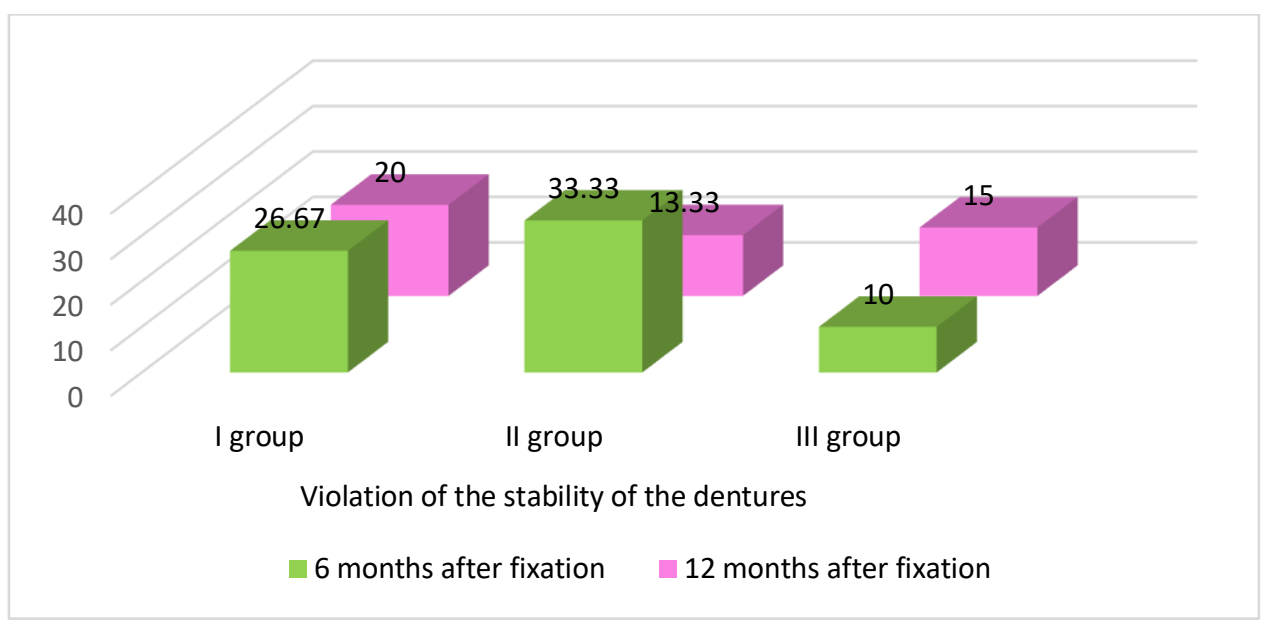

Fig. 8. Comparison of the stability of the non-removable dentures over a period between 6 and 12 months after fixation 
Patients of group II had violations of the stability of fixed dentures around 5 fixed dentures 33.33 (3.87)\% for 6 months of usage, and at examination, after 12 months the results decreased and were around 2 units $13.33(2.37) \%$, which has a significant difference $(\mathrm{p}<0.05)$ of statistical results (fig.8). In group III, this indicator was in 3 fixed orthopedic designs15.00 (2.07) $\%$ and had an insignificant $(\mathrm{p}>0.05)$ difference with the indicator of this group for 6 months $10.00(2.24) \%$

During the intraoral examination, attention was paid to the change in color of the fixed dentures (fig. 9).

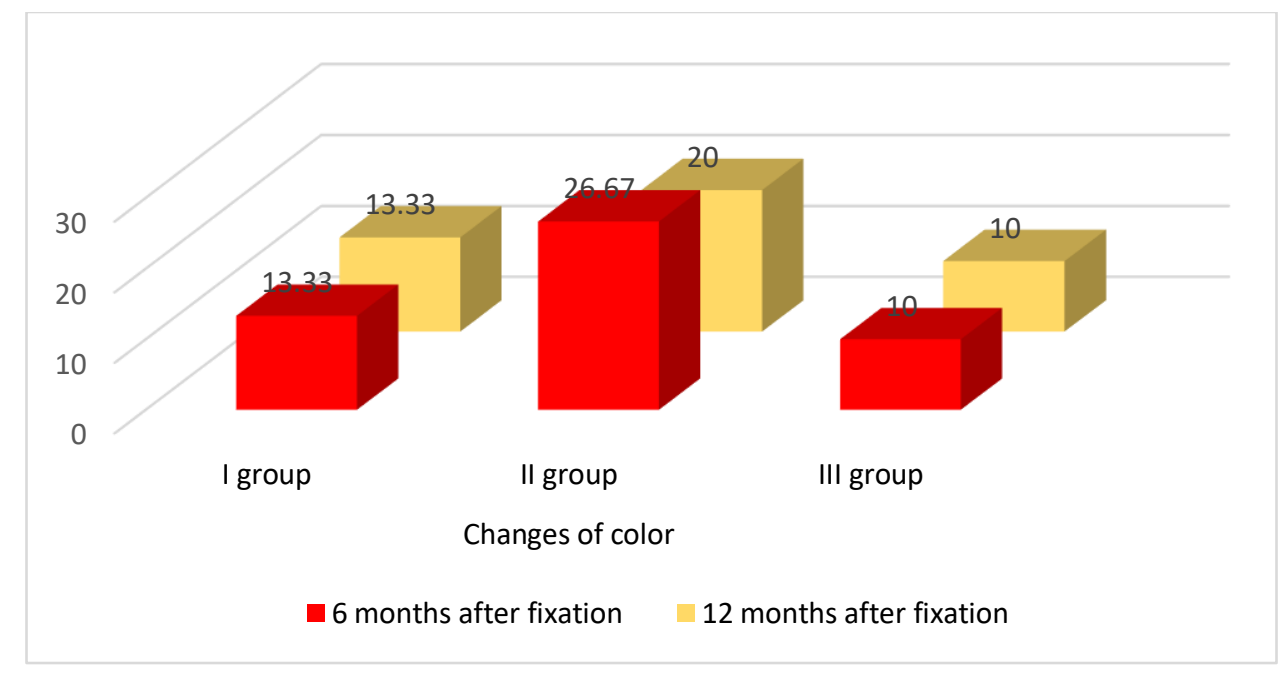

Fig. 9. The rate of change in color of fixed dental designs in comparison between 6 and 12 months after permanent fixation

The results obtained for the 12-month period did not differ significantly from the period of usage of dentures for 6 months. In group I, the change of color was detected in 2 units 13.33 (2.68) $\%$ for 6 months and for a 12-month period - 2 non-removable dentures $13.33(3.41) \%$, the data of which do not in itself a significant difference $(\mathrm{p}>0.05)$.

This figure in patients of group II for the six-month period was 26.67 (2.13)\%, which differs slightly from the figure for 12 months 20.00 (4.28) \% and has an insignificant difference with it $(\mathrm{p}>0.05)$.

In patients of the third experimental group there was a change in color for 6 months in 2 constructions $10.00(1.47) \%$ and for a 12-month period - 2 units 10.00 (1.56) \%, which indicates the inaccuracy of the data obtained $(\mathrm{p}>0.05)$. 
In patients of group II there were also 2 constructions for 6 months 13.33 (1.53) \% and 4 26.67 (3.62) \% for 12 months of use, which indicates the importance $(p<0.05)$ data (fig. 10).

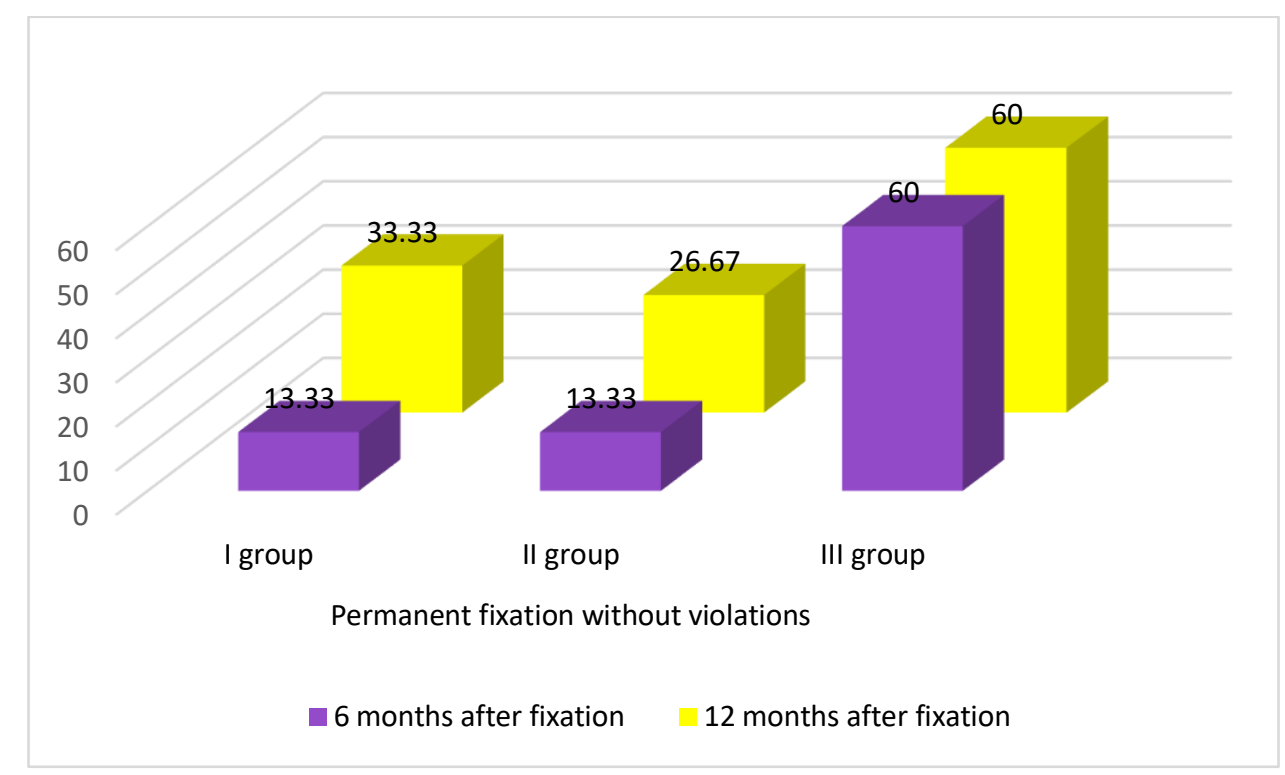

Fig. 10. Comparison of the indicator "permanent fixation without violations", observation of the period from 6 to 12 months after fixation

On the other hand, in patients of the third experimental group this indicator did not change significantly during this period, so for a 6-month period of such constructions there were 12 units $60.00(5.38) \%$ and for a 12-month period, there were also 12 fixed dentures 60.0 (3.87) $\%$.

Conclusions. The choice of the appropriate dental material for permanent fixation of fixed denture structures requires careful consideration, as it will depend on the ultimate success of orthopedic treatment. The choice of fixing cement to be used for this restoration should be based on basic knowledge of structural materials, type of indirect restoration, patient requirements, knowledge and experience of the clinician.

The conducted clinical researches will allow to tell that the domestic glass ionomer cement developed by us, in comparison with analogs has optimum clinical characteristics that allows to recommend this material in daily practice of orthopedists. 


\section{References}

1. Voznii O.V., Germanchuk S.M., Struk V.I, Bida V.I., Pogorila A.V. Stan i perspektivi rozvitku stomatologichnoï dopomogi naselennyu Ukraïni [Status and prospects of development of dental care for the population of Ukraine] Aktual'ni pitannya farmatsevtichnoï i medichnoï nauki ta praktiki [Current issues of pharmaceutical and medical science and practice] 2019. Vol. 12. № 2(30). P. 228-234. [in Ukrainian]

2. Struk V.I., Tamazlikar D.V., Mitchenok O.V. Analiz dinamiki zakhvoryuvanosti tverdikh tkanin zubiv u zhiteliv mista Chernivtsi [Analysis of the dynamics of the incidence of hard tissues of the teeth in the city of Chernivtsi] Ukraïns'kii stomatologichnii al'manakh [Ukrainian Dental Almanac] 2013. № 3. P.28-30. [in Ukrainian]

3. Slin'ko Yu.O., Sokolova I.I., Udovichenko N.M. Poshirenist' defektiv zubnikh ryadiv u doroslogo naselennya Kharkivs'kogo regionu [Prevalence of dentition defects in the adult population of the Kharkiv region] Ukraïns'kii zhurnal meditsini, biologii ta sportu [Ukrainian Journal of Medicine, Biology and Sports]. 2019. Vol. 4. № 6 (22). P. 260-265. [in Ukrainian]

4. Los' V.V., Parii V.V., Gushcha D.K., Koval' E.V., Pashkevich V.V., Dyadik I.G. Klinikopsikhologichni osoblivosti u patsientiv z patologichnimi stanami zumovlenikh koristuvannyam metalovmisnimi zubnimi protezami [Clinical and psychological features in patients with pathological conditions caused by the use of metal-containing dentures] Materialy mizhnar. stom. konf. "Aktual'ni pitannya naukovo-praktichnoï stomatologiï" [Materials international stom. conf. "Current issues of scientific and practical dentistry]. Uzhgorod. 2016. P. 212-213. [in Ukrainian] 5. Massarskii I.G. Sravnitel'naya kharakteristika metodov podgotovki opornykh zubov dlya izgotovleniya nes"emnykh protezov [Comparative characteristics of methods of preparation of abutment teeth for the manufacture of non-removable dentures]: avtoref. dis. ... kand. med. nauk. Tver'. 2015. 18 p. [in Russia].

6. Mirchuk B.M., Maximov Ya.V. Chastota defektiv zubnikh ryadiv sered doroslikh patsientiv m. Zaporizhzhya, yaki zvernulisya za protetichnim likuvannyam [Frequency of dentition defects among adult patients of Zaporizhia who applied for prosthetic treatment] Aktual'ni pitannya farmatsevtichnoï i medichnoï nauki ta praktiki [Current issues of pharmaceutical and medical science and practice]. 2017. Vol. 10. № 1(23). P. 102-106. [in Ukrainian] 
7. Bakshi Y, Ahuja N. Luting agents used in dentistry: A review of literature. J Adv Med Dent Scie Res. 2016. № 4(3). P. 46-50.

8. Yanishen I.V., Sidorova O.V. Novii vitchiznyanii skloionomerni tsement dlya postiinoï fiksatsiï neznimnikh ortopedichnikh konstruktsii [New national glass ionomer cement for permanent fixation of non-removable orthopedic structures]. Eksperimental'na ta klinichna stomatologiya [Experimental and clinical dentistry]. Kharkiv. 2019. № 4. P. 36-40. [in Ukrainian] 9. Yanishen I.V. Sidorova O.V., Biryukov V.O., Yarova A.V., Krinichko F.R. Viznachennya mitsnosti adgeziï skloionomernikh tsementiv dlya postiinoï fiksatsiï do riznomanitnikh konstruktsiinikh metaliv pri poperednii piskostrumnii obrobtsi [Determination of the adhesion strength of glass ionomer cements for permanent fixation to various structural metals during preliminary sandblasting] The 5th International scientific and practical conference "Topical issues of the development of modern science" (January 15-17, 2020). - P.1049-1055. [in Ukrainian]

10. I. Yanishen, I. Diudina, N. Krychka [et al.] Experimental justification of a method-ofchoice to protect the receptor apparatus of the teeth, supporting a non-removable design denture. Georgian Medical News. 2019. №. 1 (286). P. 36-39.

11. Perepelova T.V., Mishchenko S.V., Khmil' T.A., Khrebor M.V., Silenko Yu.I., Sokolenko V.M. Osoblivosti elektroprovidnosti i oporu fiksuyuchikh tsementiv dlya neznimnikh ortopedichnikh konstruktsii [Features of electrical conductivity and resistance of fixing cements for fixed orthopedic structures].Ukraïns'kii stomatologichnii al'manakh [Ukrainian Dental Almanac]. 2017. № 2. P. 36-38. [in Ukrainian]

12. Galip Gurel, Marcelo A. Calamita, Christian Coachman. Clinical Performance of Porcelain Laminate Veneers: Outcomes of the Aesthetic Pre-evaluative Temporary (APT) Technique. The International Journal of Periodontics \& Restorative Dentistry. 2012. Vol. 32. № 6. P.624-635.

13. Mutlu Özcan, Mine Dündar, M. Erhan Çömlekoğlu. Adhesion concepts in dentistry: tooth and material aspects. Journal of Adhesion Science and Technology. 2012. Vol. 26. № 24. P. 2661- 2681. 